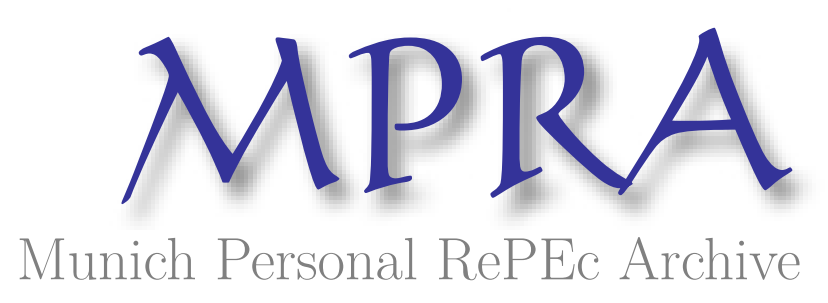

\title{
Were Canadian Exports to the U.S. \\ Curtailed by the Post-9/11 Thickening of the U.S. Border?
}

Grady, Patrick

Global Economics Ltd.

9 October 2009

Online at https://mpra.ub.uni-muenchen.de/21047/

MPRA Paper No. 21047, posted 04 Mar 2010 03:33 UTC 


\title{
Were Canadian Exports to the U.S. Curtailed by the Post-9/11 Thickening of the U.S. Border?
}

\author{
Patrick Grady \\ Global Economics Ltd.
}




\begin{abstract}
:
The paper examines the data for Canadian exports to the United States that have been cited as prima facie evidence of a "thickening of the border." It estimates that Canadian exports of goods, excluding energy and forestry products, to the United States have been 12.5 per cent lower than would have been expected based on estimated relationships and exports of services 8 per cent lower. These estimates suggest that the boost to Canadian exports resulting from the FTA/NAFTA has been substantially eroded.
\end{abstract}

JEL Classification Codes: F14 - Country and Industry Studies of Trade; F15 - Economic Integration; F53 - International Agreements and Observance; International Organizations.

\title{
Keywords:
}

English: Canadian Exports, Canada-U.S. Border, Post 9/11 Security, Free Trade Agreement, North American Free Trade Agreement 


\section{Introduction}

After the terrorist attack on New York and Washington on September 11, 2001, the United States Government introduced a series of measures designed to tighten security at the Canada-U.S. border. It has become a commonly-held belief in Canada that these measures collectively have had a very adverse effect on Canadian trade and the very thought of them conjures up images of large lines of trucks waiting at the border in the minds of many Canadians. Canadian Ambassador Michael Wilson said "We call it a thickening of the border” (Ryan, 2007). Most recently, Federal Industry Minister Jim Prentice complained about mounting border delays and warned about the "thickening of the border" resulting from enhanced security measures (Alberts, 2008). Many observers have commented on this phenomenon and provide many concrete examples of tightening (Robson and Goldfarb, 2003; Goldfarb, 2007; Hart , 2008a\&b; Hufbauer and Brunel, 2008; Corcoran, 2008; and Gastle and Martyn, 2008).

In a joint report prepared earlier in 2008, the Canadian and U.S. Chambers of Commerce contended that based on the feedback that they had received from Canadian and U.S. businesses there was "an increase in border costs and a 'thickening' of the border because of increased wait times; direct fees for crossing the border; additional and duplicative border programs; additional costs for participating in trusted shipper and traveler programs; and increased inspection times." (Canadian Chamber of Commerce, 2008:1). Because of their concern about the "increasing costs and delays associated with crossing the border," they made practical recommendations to reduce border costs without compromising security. 
In its report to NAFTA Leaders, The North American Competitiveness Council lamented that "Businesses in Canada, Mexico, and the United States are bearing the burden of new measures to enhance security, as well as more rigorous enforcement of existing rules", and complained that "This means that businesses in all three countries are facing longer delays, higher inspection rates, additional fees, and more layers of security when they can afford it least" (North American Competitiveness Council, 2008: 4-5). These articles and studies contribute to a growing literature documenting the various ways in which U.S. border controls have been tightened after 9/11, restricting trade between Canada and the United States.

A Fraser Institute study summarized the studies attempting to measure increased border costs after $9 / 11$ and estimated that the "waiting, processing and security measures costs at 2 to 3 per cent of total trade" (Moen and Cust, 2008: 12). The studies surveyed for the estimate were done by: KPMG; the Michigan Department of Transportation; Transport Canada; the Canada-U.S. Trade Center at the State University of New York at Buffalo; and the Conference Board. The important contribution of these studies is that they reveal the costs imposed on traders by the tightening of U.S. border controls.

On the other hand, it must be recognized that measures have also been introduced to facilitate the cross border flows of goods and people. These include trusted shipper programs like FAST and NEXUS cards for low risk travelers.

This paper examines the issue of the "thickening" of the border from a different perspective than these studies mentioned above. Rather than focusing on the specific measures 
contributing to the "thickening" of the border and the related policy issues and seeking to quantify their costs, its contribution is to present the statistical data on Canadian exports, and to analyze them using econometric tools to provide quantitative estimates of the impact of the post 9/11 tightening on Canadian exports. In adopting this approach, this paper most closely resembles studies done by Globerman and Storer (2008) and Burt (2007). However, unlike these other studies, this paper does not consider imports because they should not affected directly by the tightening of U.S. border controls after 9/11 but only by Canadian border control measures (except, of course, to the extent they are inputs to exports, which is an increasingly important phenomena with value chains often crossing the border several times). An exception is Canadian travel payments to the United States, which are examined because of the increased scrutiny of Canadian travelers entering the United States that occurred after 9/11. It also considers exports of services such as commercial services, transportation services, and travel, which were not included in the other two studies.

\section{The Trade Data ${ }^{1}$}

\section{Exports of Goods}

The data for exports of goods have been cited as prima facie evidence of a "thickening of the border" (Statistics Canada, Catalogue 65-001 XIB). After more than a decade of strong growth following the 1989 Canada-U.S. Free Trade Agreement, the growth of Canadian exports of goods to the United States in current dollars stalled after the year 2000, declining slightly from $\$ 334.1$ billion in 2000 to $\$ 331.4$ billion in 2007 . The share of exports of goods going to the United States fell more significantly from 86.7 per cent in 2000 to 79.3 per cent 
in 2007. The decline in exports of goods to the United States as a share of GDP from 31 per cent in 2000 to 21.6 per cent in 2000 is even more striking as exports had grown more rapidly than GDP after the implementation of the FTA/NAFTA (Figure 1).

The source of the weakness in current dollar exports is shown in Figure 2 to be non-energy exports. Energy exports were the only component of exports that continued to grow strongly after 9/11. Forestry Products exhibited a particular weakness after 2000, dropping by over a third from $\$ 32.4$ billion in 2000 to $\$ 21.1$ billion in 2007 . This was the result of restrictive trade actions taken in the United States against softwood lumber exports. Hence, total exports to the United States excluding forestry products as well as energy, also declined more than total exports, but by less than total exports excluding energy.

In order to better understand the forces behind the trends in exports to the United States, it is useful to take a look at exports in constant chained 2002 dollars (Figure 3). This provides a more accurate depiction of the volume of exports as some export categories such as energy and other commodities experienced large price increases over the period. In constant dollars, the stagnation of exports after $9 / 11$ is thus even more evident once the impact of price increases is removed. The similarity in the trends in current and constant dollar for most other export categories stems from the small changes that occurred in prices over the period in part reflecting the strong appreciation of the Canadian dollar after 2002. 


\section{Exports of Services}

Exports of services to the United States also exhibited significant weakness after 9/11, falling from 3.4 per cent of GDP in 2000 to 2.7 per cent of GDP in 2005 (Figure 1 shows exports of goods and exports of goods and services, the difference being services). The weakness was more pronounced in travel and transportation services with commercial services continuing to increase after 9/11, albeit at a much slower pace, (Figure 4). The decline in exports of travel services was greatest for personal travel (Figure 5). This might be considered surprising as the Canadian Government took no steps to make entry into Canada more difficult. But the much discussed and several times postponed Western Hemisphere Travel Initiative, which imposes a requirement that returning U.S. citizens present a passport or equivalent document to reenter the United States, has had a depressing impact on the travel of U.S. residents to Canada even before it came into effect. The reason for this is that it gave rise to much confusion about requirements at the border. In fact, passports were not actually required for air travel until after January 23, 2007 and are currently supposed to be required at sea and land borders only after July 1, 2009. The post-9/11 weakness in exports of transportation services was greatest for air transportation, which actually declined by 44 per cent between 2000 and 2007 (Figure 6).

\section{Imports of Travel Services}

Imports of travel services are affected by U.S. border controls. In this, they are more like exports than like other imports, which are affected by Canadian, rather than American, border controls. Travel imports declined after 2000 in current dollars, but then recovered in 2004 and surpassed 2000 levels (Figure 7). This pattern was shaped by personal travel imports. Business travel exhibited a much flatter pattern after 2000. The decline in travel 
imports and the subsequent recovery is more pronounced in constant dollars than in current (Figure 8).

\section{Econometric Analysis of the Trade Data}

An examination of the trends in exports provides an impression of the impact of $9 / 11$ on exports of goods and service and travel imports. But to disentangle the impact of the various economic factors at play, such as the strong appreciation of the Canadian dollar that occurred after 2002 and the continued growth in the U.S. economy, requires more sophisticated econometric analysis.

\section{Exports of Goods}

The export of goods from Canada to the United States obviously depends on demand factors in the United States and supply factors in Canada. An econometric model capturing all of the interdependencies would involve many interrelated supply and demand equations and necessarily be very complex. Inevitably, its estimation would involve many statistical problems such as identification and simultaneity. However, since the purpose here is not to develop an accurate structural model of Canadian exports to the United States, but merely to see if 9/11 had an impact on the relationships, a more simple reduced form approach was utilized. It involved specifying the simplest possible relationship that is able to capture the main interdependencies and then testing to see if the constant term in that relationship changed after $9 / 11$ by adding a dummy variable. The choice of the simplest and most obvious possible relationship should serve to reassure readers that no data mining was involved in this exercise to produce desired results. The particular relationship used specifies that constant dollar exports of the particular category of goods is a function of U.S. real GDP, which proxies U.S. real income, and relative prices converted to a common currency using 
the exchange rate, which represents cost. This specification most closely resembles a U.S. demand function for imports. It is in the tradition of gravity models that have often been used to estimate import equations. The relationship is specified in logarithms, with a constant term and a dummy variable for after $9 / 11$. The use of logarithms allows the coefficients on GDP and relative prices to be interpreted as elasticities and the coefficient on the post 9/11 dummy variable to be interpreted as a percentage impact. The equation to be estimated can be written as follows:

$$
\log \left(\text { Exports }_{\mathrm{i}}\right)=\mathrm{a}+\mathrm{b}^{*} \log \left(\mathrm{GDP}_{\mathrm{US}}\right)+\mathrm{c} *\left(\mathrm{PFX}^{* \mathrm{PGDP}_{\mathrm{CAN}}} / \mathrm{PGDP}_{\mathrm{US}}\right)+\mathrm{d}^{*} \mathrm{D} 911+\varepsilon
$$

Where: Exports $\mathrm{i}_{\mathrm{i}}$ is exports for category $\mathrm{i}$ of exports in constant dollars;

GDP $_{\text {US }}$ is Gross Domestic Product in the United States in constant dollars; PFX is the cost of a Canadian dollar in U.S. dollars; PGDP $_{\mathrm{CAN}}$ is the price deflator for Canadian GDP; PGDP $_{\text {US }}$ is the price deflator for U.S. GDP; D911 is equal to 1 after 2000 except in 2001 when it equals 0.3333 reflecting the part of the year falling after September 11); and $\varepsilon$ is a random disturbance term.

The estimation results are provided for the eight available categories of exports as well as the total (Table 1). The results are also provided for the total excluding energy and the total excluding energy and forestry products. This was done since energy and forestry products exports have been affected by special factors other than the post 9/11 border tightening. Specifically, Canada is a secure supplier of energy and has, as a result, been able to expand 
its exports to the United States, including through the development of the Alberta oil sands. And forestry product exports have been subject to continuing restrictions under the softwood lumber dispute, which would likely be more important than any post 9/11 border thickening. For both of these export categories, these special factors were more important than any post 9/11 border tightening.

The simple specification provides a very close fit for most categories and the totals as evidenced by the high adjusted coefficient of determination (adjusted $\mathrm{R}^{2}$ ) shown in Table 1 . The exceptions are for forestry products and energy, as was expected, and also for automotive products. In all cases, there is a highly significant relationship between real exports and the logarithm of U.S. real GDP. The elasticities with respect to the U.S. real GDP are also high, being significantly greater than 1 except for energy and forestry product exports. Relative cost is also significant with the correct negative sign (indicating that higher prices in Canada than in the United States in a common currency exert a negative impact on exports as does an appreciation of the Canadian dollar in terms of the U.S. unit) except for energy and automotive products. This is important because it is necessary to be able to quantify the effect of the recent appreciation of the Canadian dollar on exports to separate it from the impact of the post-9/11 border thickening. The elasticity of exports with respect to relative costs is not too far from unity for the three total categories. This means, for example, that the direct impact of a 10 per cent appreciation of the dollar would be to lower exports by 10 per cent, which is a fairly large impact. While the post-9/11 dummy has the correct negative sign for 6 of the 8 categories of exports, it is only significant for two: machinery and equipment, and special transactions. Nevertheless, the post-9/11 dummy is highly significant for the three total categories. And its magnitude suggests that there was a 
very large reduction in total exports of 9.3 per cent for total exports to the United States or 12.5 per cent for total exports excluding energy and forestry products. The estimate of the border thickening using the estimated equation for exports excluding energy and forestry products is shown in Figure 9. ${ }^{3}$

It is worth noting that the estimated reduction in exports is substantial even in relation to the likely positive effect of the FTA/NAFTA on Canadian exports. It should be remembered that the U.S. tariffs levied on Canadian imports, which were eliminated, only averaged around 1 per cent in 1987, the year before the Canada U.S. free trade agreement came into effect. ${ }^{2}$ The near unity coefficient on the relative price term in the equation suggests that a tariff reduction of that magnitude would only by itself increase Canadian exports to the United States by around one percent. The overall effect of FTA/NAFTA would, of course, be much larger since there were non-tariff as well as tariff barriers that were removed.

\section{Exports of Services}

Equations were also estimated using the same simple specification for exports of the various categories of services (Table 2). The equations, except for exports of personal travel services,

explained a very high proportion of the variance of the series as measured by the adjusted $\mathrm{R}^{2}$.

U.S. real GDP and relative costs were highly significant and with the right signs as

explanatory variable in all of the equations. The dummy variable for the shift in the constant

term after 9/11 was also significant except for total travel services. The coefficient in the total equation suggests that the three services were about 8 per cent lower after September 11, 2001 than would have been expected on the basis of previous trends. 
Exports of travel services are different from other services in that they involve U.S. resident persons and businesses crossing over the Canadian border. Consequently, in theory, they should not be directly affected by any tightening up of the U.S. border. However, in practice, they could have been affected by the uncertainty surrounding the Western Hemisphere Travel Initiative and concerns about reentering the United States.

Even though the coefficient on the $9 / 11$ dummy turned out to be not significant in the estimated equation for total travel service, it turned out to be highly significant in the equation for the export of business travel services. This is somewhat surprising as knowledge of border requirements should be higher among business travelers. But a possible explanation for the lower level of business travel is the overall lower level of trade.

\section{Imports of Travel Services}

Finally, equations were estimated for imports of travel services (Table 3). These would have been affected directly by any tightening of requirements for admission to the United States or enhanced screening introduced at the U.S. border. Since these equations reflect Canadian demand for travel to the United States, the relevant income variable is Canadian real GDP, rather than U.S. real GDP as for the exports of travel services. In the results, imports of travel service, particularly for the more important personal travel, turn out to be less sensitive to income as revealed by the coefficient of Canadian real GDP, and imports of personal travel services are highly sensitive to relative cost. This is important because an important part of the explanation for the weakness in imports of travel services after $9 / 11$ is the large appreciation of the Canadian dollar that started in 2002. Nevertheless, the coefficient on the 9/11 dummy still turned out to be highly significant in the equation for imports of total travel 
services. However, it is larger and more significant for business travel services. This could reflect the link between imports of business travel services and exports of goods, which were depressed after 9/11. The coefficient on the dummy variable suggests that imports of personal travel services were 7.4 per cent lower than would have been expected based on past trends after $9 / 11$ and imports of business services were 32.5 per cent lower. This is because imports of business travel services would have tended to increase more in line with Canadian real GDP and were less sensitive to relative cost considerations.

\section{Conclusions}

The econometric analysis presented in this paper confirms the earlier analysis of Globerman and Storer (2008) and provides empirical support to back up the many complaints made that there has been a "thickening of the border" after 9/11. It estimates that Canadian exports of goods, excluding energy and forestry products, to the United States have been 12.5 per cent lower than would have been expected based on estimated relationships. It should be noted that this is substantial negative impact on exports even in comparison with the likely positive impact of the FTA/NAFTA, which, even though it reduced non-tariff barriers, only eliminated tariffs averaging around one per cent. The analysis also confirmed that there was an 8-per-cent negative impact on the exports of services to the United States and an almost 13 per cent on the imports of travel services. It is ironic to consider such large estimates of the negative impact on Canadian exports of the post-9/11border tightening at the same time as opposition to NAFTA is being expressed in the United States. Indeed, it could be argued, based on the analysis presented in this paper, that the any positive impact of the FTA/NAFTA on imports from Canada have already been substantially eroded. 


\section{Notes}

* The author wishes to thank William Robson, Krista Lucenti, Phillip Smith, Shenjie Chen and Gary Hufbauer for helpful comments.

1. Before discussing the trends in the relevant data series, there are a few points that need to be made about the data themselves. The first point is that the relevant series for exports to the United States are not all available and up-to-date on Statistics Canada's CANSIM data base. Specifically, the data for the 8 categories of domestic exports of goods to the U.S. are not available on CANSIM at all, either on a customs or balance of payments basis. When a request for a quote on the cost of obtaining the 8 series plus the total for the period from 1966 to 2007 was made, the resulting cost estimate was $\$ 3,960$ (plus GST). When the period was cut to 1995 to 2007 , the cost estimate was reduced to $\$ 1,330$ (plus GST) As this was still too costly for a nonfunded project like this, the data was obtained manually from the back issues for December of years 1995 to 2007 of Canadian International Merchandise Trade, catalogue 65-001 XIB. The data for the proceeding year was used to try to capture revisions, even though this has the disadvantage of missing any revisions taking place after a year, which hopefully would be small. And for converting the current dollar exports of goods to constant dollar, no data was available for the deflators for the various categories of exports of goods to the U.S. but only for total exports of goods for the particular category from the economic accounts. Concerning the data for the various categories of exports of services to the U.S., they are available in current dollars on CANSIM, but are a year out of date (2006 only available in April 2008). 
And no data are available for the deflators for the various categories of exports of services to the U.S. but only for total exports of services for the particular category on a balance of payments basis. The point of this long digressive note is to deplore the lack of readily accessible and affordable data on something as basis as Canadian exports to the United States on both a customs and balance of payments basis in both current and chained 2002 dollars. It is also to present yet another example of the extent to which the aggressive application of Statistics Canada's cost recovery policy ( $\$ 1,330$ for 9 series that can be copied from a book and that in any event should be publicly available on CANSIM) can potentially stifle independent research into one of the most important economic policy issues facing Canada.

2. The one per cent estimate of average U.S. tariffs levied on Canadian imports was based on a series for duties paid on Canadian imports that was prepared by U.S. agencies at the request of Statistics Canada for 1983 to 1987 . The precise number provided by Shenjie Chen of Foreign Affairs and International Trade Canada for use in an earlier paper was 0.98 per cent for 1987 (Grady and Macmillan, 1998: 32-34).

3. Two other empirical studies of the impact of $9 / 11$ on exports were called to my attention by Krista Lucenti of the C.D. Howe Institute. The first by Globerman and Storer (2008) estimates equations for both U.S. imports from Canada and U.S. exports to Canada using quarterly data from 1996Q1 to 2005Q2 for current dollar trade flows in U.S. dollars (equations were also estimated for different ports using more disaggregated data from the U.S. Bureau of the Census). The explanatory variables in their aggregate gravity model are U.S. and Canadian GDP and the 
Canada-U.S. exchange rate as well as a dummy for post $9 / 11$. Their conclusion is that U.S. imports from Canada were 12.2 per cent lower in the first half of 2005 than it would have otherwise been based on pre-9/11 trends. This is of the same order of magnitude of the results reported in this paper even though their estimates of the impact in earlier years are much larger.

The second study was by Michael Burt (2007) for the Conference Board. It differed from the Globerman and Storer (2008) study in that it used: real trade data rather than nominal; a relative cost variable rather than just the exchange rate; a longer sample running from 1988 to 2005; and commodity and port specific drivers as explanatory variables in the port and commodity specific equations estimated (for 12 ports and 12 commodities). In contrast with Globerman and Storer (2008), it found "no evidence of a significant reduction in total export volumes due to tighter border security." It attributed the weakness of exports to "industry-specific factors such as the tech bust and the softwood lumber dispute." 


\section{References}

Alberts, Sheldon. (2008). Prentice sounds alarm over 'thickening' U.S. border. Financial Post. May 07, A1.

Burt, Michael. (2007). Tighter Border Security and Its Effect on Canadian Exports. Report, International Trade and Investment Centre, Conference Board of Canada. June.

Canadian Chamber of Commerce and U.S. Chamber of Commerce. (2008). Finding the Balance: Reducing Border Costs While Strengthening Security. February.

Corcoran, Terence. (2008). U.S. border is killing free trade. Financial Post. February 12.

Gastle, Chuck and Martyn, Murdoch. (2008). NAFTA just not what it used to be: The inability to solve the softwood lumber dispute points to the trade deal's weakness. The Toronto Star, Mar 9.

Globerman, Steven and Storer, Paul. (2008). The Impacts of 9/11 on Canada-U.S. Trade. Toronto, University of Toronto Press.

Goldfarb, Danielle and Robson, William BP. (2003). Risky Business: U.S. Border Security and the Threat to Canadian Exports. C.D. Howe Institute Commentary. No. 177. March.

Goldfarb, Danielle. (2007). Reaching a Tipping Point: Effects of Post 9/11 Border Security on Canada's Trade and Investment. Report, International Trade and Investment Centre, Conference Board of Canada. June.

Grady, Patrick and Macmillan, Kathleen. (1998). Why is Interprovincial Trade Down and International Trade Up? Canadian Business Economics. 6(4), 26-35.

Hart, Michael. (2008a). What about the Border? In One Issue: Two Voices. the Canada Institute, Woodrow Wilson International Center for Scholars. February, 8-13.

Hart, Michael. (2008b). Canada blew it: Security barriers raised since 9/11 divide Canadians and Americans more than they ward off terrorists. Financial Post. February 12.

Hufbauer, Gary and Brunel, Clare. (2008). Economic Integration in North America. In One Issue: Two Voices. the Canada Institute, Woodrow Wilson International Center for Scholars. February, 2-7.

Moens, Alexander and Cust, Michael. (2008). Saving the North American Security and Prosperity Partnership: The Case for a North American Standards and Regulatory Area. Fraser Institute Digital Publication. March. 
North American Competitiveness Council. (2008). Meeting the Global Challenge: Private Sector Priorities for the Security and Prosperity Partnership of North America, Report to Leaders, April.

Ryan, Missy. (2007). Trade, travel issues at U.S. border rankle Canada. Reuters, June 25.

Statistics Canada. Canadian International Merchandise Trade. Catalogue 65-001 XIB, December issue for years 1995-2007. 


\section{Tables}

\begin{tabular}{|c|c|c|c|c|c|c|}
\hline \multicolumn{7}{|c|}{$\begin{array}{l}\text { Table 1: Regression Results for the Log of Real Export of Goods to the U.S. } \\
\text { in Constant Dollars }\end{array}$} \\
\hline $\begin{array}{l}\text { Export Product } \\
\text { Category }\end{array}$ & Intercept & $\begin{array}{l}\text { Log of US } \\
\text { Real GDP }\end{array}$ & $\begin{array}{l}\text { Relative } \\
\text { Cost }\end{array}$ & $\begin{array}{l}\text { 9/11 } \\
\text { Dummy }\end{array}$ & Adj. $R^{2}$ & D.W. \\
\hline $\begin{array}{l}\text { Agriculture and } \\
\text { Fishing }\end{array}$ & $\begin{array}{l}-11.94448 \\
(-10.43) * *\end{array}$ & $\begin{array}{l}2.443283 \\
(19.13) * *\end{array}$ & $\begin{array}{l}-1.112398 \\
(-10.84)^{* *}\end{array}$ & $\begin{array}{l}-0.018869 \\
(-0.66)\end{array}$ & 0.9873 & 1.88 \\
\hline Energy & $\begin{array}{l}-10.83764 \\
(2.96)^{*}\end{array}$ & $\begin{array}{l}0.722551 \\
(4.60) * *\end{array}$ & $\begin{array}{l}-0.180674 \\
(-1.43)\end{array}$ & $\begin{array}{l}0.034468 \\
(0.98)\end{array}$ & 0.8821 & 2.46 \\
\hline Forestry & $\begin{array}{l}2.088617 \\
(0.87)\end{array}$ & $\begin{array}{l}0.951612 \\
(3.54) * *\end{array}$ & $\begin{array}{l}-0.783293 \\
(-3.63) * *\end{array}$ & $\begin{array}{l}-0.047875 \\
(-0.80)\end{array}$ & 0.6406 & 1.34 \\
\hline Industrial Goods & $\begin{array}{l}-2.871686 \\
(-2.14)\end{array}$ & $\begin{array}{l}1.551276 \\
(10.39) * *\end{array}$ & $\begin{array}{l}-0.946393 \\
(-7.89) * *\end{array}$ & $\begin{array}{l}-0.058603 \\
(-1.76)\end{array}$ & 0.9457 & 1.68 \\
\hline $\begin{array}{l}\text { Machinery and } \\
\text { Equipment }\end{array}$ & $\begin{array}{l}-14.17179 \\
(-8.82) * *\end{array}$ & $\begin{array}{l}2.865405 \\
(16.00)^{* *}\end{array}$ & $\begin{array}{l}-1.502191 \\
(-10.43)^{* *}\end{array}$ & $\begin{array}{l}-0.268332 \\
(-6.71)^{* *}\end{array}$ & 0.9662 & 2.72 \\
\hline Automotive & $\begin{array}{l}-2.659561 \\
(-1.11)\end{array}$ & $\begin{array}{l}1.564201 \\
(5.85)^{* *}\end{array}$ & $\begin{array}{l}-0.435830 \\
(-2.03)\end{array}$ & $\begin{array}{l}-0.088907 \\
(-1.49)\end{array}$ & 0.8365 & 2.05 \\
\hline Consumer Goods & $\begin{array}{l}-19.37756 \\
(-6.60) * *\end{array}$ & $\begin{array}{l}2.888600 \\
(8.83) * *\end{array}$ & $\begin{array}{l}-1.835357 \\
(-6.98) * *\end{array}$ & $\begin{array}{l}0.093819 \\
(1.28)\end{array}$ & 0.9546 & 1.36 \\
\hline $\begin{array}{l}\text { Special } \\
\text { Transactions }\end{array}$ & $\begin{array}{l}-28.85635 \\
(-11.94)^{* *}\end{array}$ & $\begin{array}{l}4.254637 \\
(15.80)^{* *}\end{array}$ & $\begin{array}{l}-2.160980 \\
(-9.98)^{* *}\end{array}$ & $\begin{array}{l}-0.152026 \\
(-2.53)^{*}\end{array}$ & 0.9766 & 1.70 \\
\hline Total & $\begin{array}{l}-4.776110 \\
(-4.78) * *\end{array}$ & $\begin{array}{l}1.958819 \\
(17.59) * *\end{array}$ & $\begin{array}{l}-0.840422 \\
(-9.39) * *\end{array}$ & $\begin{array}{l}-0.093072 \\
(-3.74) * *\end{array}$ & 0.9797 & 1.91 \\
\hline $\begin{array}{l}\text { Total excluding } \\
\text { Energy }\end{array}$ & $\begin{array}{l}-6.975383 \\
(-5.66)^{* *}\end{array}$ & $\begin{array}{l}2.190857 \\
(15.95)^{* *}\end{array}$ & $\begin{array}{l}-0.964509 \\
(-8.74)^{* *}\end{array}$ & $\begin{array}{l}-0.115915 \\
(-3.78)^{* *}\end{array}$ & 0.9743 & 1.95 \\
\hline $\begin{array}{l}\text { Total excluding } \\
\text { Energy and } \\
\text { Forestry }\end{array}$ & $\begin{array}{l}-8.638156 \\
(-7.44)^{* *}\end{array}$ & $\begin{array}{l}2.361591 \\
(18.26)^{* *}\end{array}$ & $\begin{array}{l}-0.999416 \\
(-9.61)^{* *}\end{array}$ & $\begin{array}{l}-0.125036 \\
(-4.33)^{* *}\end{array}$ & 0.9804 & 2.10 \\
\hline \multicolumn{7}{|c|}{$\begin{array}{l}\text { Note: First numbers in the cells are coefficients; second numbers in parenthesis are t- } \\
\text { statistics. * signifies significant at } 5 \text { per cent level; ** at } 1 \text { per cent level. } \\
\text { The equations were estimated over the } 1995 \text { to } 2007 \text { with } 13 \text { observations. The start and end } \\
\text { points of the regressions were determined by the availability of published data. }\end{array}$} \\
\hline
\end{tabular}




\begin{tabular}{|c|c|c|c|c|c|c|}
\hline $\begin{array}{l}\text { Export } \\
\text { Category }\end{array}$ & Intercept & $\begin{array}{l}\text { Log of } \\
\text { US Real } \\
\text { GDP }\end{array}$ & \begin{tabular}{|l} 
Relative \\
Cost
\end{tabular} & $\begin{array}{l}\text { 9/11 } \\
\text { Dummy }\end{array}$ & $\begin{array}{l}\text { Adj. } \\
\mathbf{R}^{2}\end{array}$ & D.W. \\
\hline Travel & $\begin{array}{l}-0.7 \\
(-0 .\end{array}$ & $\begin{array}{l}1.203276 \\
(7.19)^{* *}\end{array}$ & $\begin{array}{l}-1.62 \\
(-10.4\end{array}$ & $\begin{array}{l}3854 \\
5\end{array}$ & 0.9338 & 2.57 \\
\hline Travel Personal & $\begin{array}{l}-1.0 \\
(-0.7\end{array}$ & $\begin{array}{l}1.221936 \\
(7.90)^{* *}\end{array}$ & $\begin{array}{l}-1.792 \\
(-12.4\end{array}$ & $\begin{array}{l}7513 \\
)\end{array}$ & 0.9526 & 2.56 \\
\hline Trave & $\begin{array}{l}-2.357896 \\
(-0.87)\end{array}$ & $\begin{array}{l}1.148822 \\
(3.85)^{* *}\end{array}$ & $\begin{array}{l}-0.920 \\
-3.32\end{array}$ & 9677 & 0.6843 & 2.16 \\
\hline Transportation & $\begin{array}{l}-0.258253 \\
(-0.17)\end{array}$ & $\begin{array}{l}1.066197 \\
(6.37)^{* *}\end{array}$ & $\begin{array}{l}-1.2 \\
(-7 .\end{array}$ & $\begin{array}{l}-0.1 \\
(-4.1\end{array}$ & 0.8979 & 2.42 \\
\hline Commercial & $\begin{array}{l}-13.08255 \\
(-11.03)^{* *}\end{array}$ & $\begin{array}{l}2.57 \\
(19 .\end{array}$ & $\begin{array}{l}-0.9 \\
(-8.0\end{array}$ & $\begin{array}{l}-0.072228 \\
(-2.49)^{*}\end{array}$ & 0.9873 & 2.41 \\
\hline $\begin{array}{l}\text { Total of Travel, } \\
\text { Transp. \& } \\
\text { Commercial }\end{array}$ & $\begin{array}{l}-6.514159 \\
(-8.52) * *\end{array}$ & $\begin{array}{l}1.932331 \\
(22.90)^{* *}\end{array}$ & $\begin{array}{l}-1.146718 \\
(-14.65)^{* *}\end{array}$ & $\begin{array}{l}-0.079853 \\
(-4.27)^{* *}\end{array}$ & 0.9896 & 2.80 \\
\hline \multicolumn{7}{|c|}{$\begin{array}{l}\text { Note: First numbers in the cells are coefficients; second numbers in parenthesis are t- } \\
\text { statistics. * signifies significant at } 5 \text { per cent level; ** at } 1 \text { per cent level. } \\
\text { The equations were estimated over the } 1995 \text { to } 2006 \text { with } 12 \text { observations. The } \\
\text { starting point was chosen to be the same as for the exports of goods equations and the } \\
\text { end point was determined by the most recent data available. }\end{array}$} \\
\hline
\end{tabular}




\begin{tabular}{|c|c|c|c|c|c|c|}
\hline $\begin{array}{l}\text { Import } \\
\text { Category }\end{array}$ & Intercept & $\begin{array}{l}\text { Log of } \\
\text { Canadian } \\
\text { Real GDP }\end{array}$ & $\begin{array}{l}\text { Relative } \\
\text { Cost }\end{array}$ & $\begin{array}{l}\text { 9/11 } \\
\text { Dummy }\end{array}$ & Adj. $\mathbf{R}^{2}$ & D.W. \\
\hline Total & $\begin{array}{l}4.338816 \\
(2.39)^{*}\end{array}$ & \begin{tabular}{|l|}
0.308596 \\
$(2.35)^{*}$
\end{tabular} & $\begin{array}{l}1.217054 \\
(9.78) * *\end{array}$ & $\begin{array}{l}-0.128257 \\
(-3.89)^{* *}\end{array}$ & 0.9007 & 2.41 \\
\hline Personal & $\begin{array}{l}6.106733 \\
(2.56)^{*}\end{array}$ & \begin{tabular}{|l|}
0.152431 \\
$(0.88)$
\end{tabular} & $\begin{array}{l}1.431270 \\
(8.74) * *\end{array}$ & $\begin{array}{l}-0.074075 \\
(-1.71)\end{array}$ & 0.8793 & 2.19 \\
\hline Business & $\begin{array}{l}-4.308404 \\
(-0.83)\end{array}$ & \begin{tabular}{|l|}
0.864767 \\
$(2.30)$
\end{tabular} & $\begin{array}{l}0.372510 \\
(1.05)\end{array}$ & $\begin{array}{l}-0.325213 \\
(-3.46)^{* *}\end{array}$ & 0.4788 & 1.97 \\
\hline
\end{tabular}

Note: First numbers in the cells are coefficients; second numbers in parenthesis are tstatistics. * signifies significant at 5 per cent level; ** at 1 per cent level.

The equations were estimated over the 1995 to 2006 with 12 observations. The starting point was chosen to be the same as for the exports of goods equations and the end point was determined by the most recent data available. 


\section{Figures}

Figure 1: Exports to the United States

$\%$ of

GDP

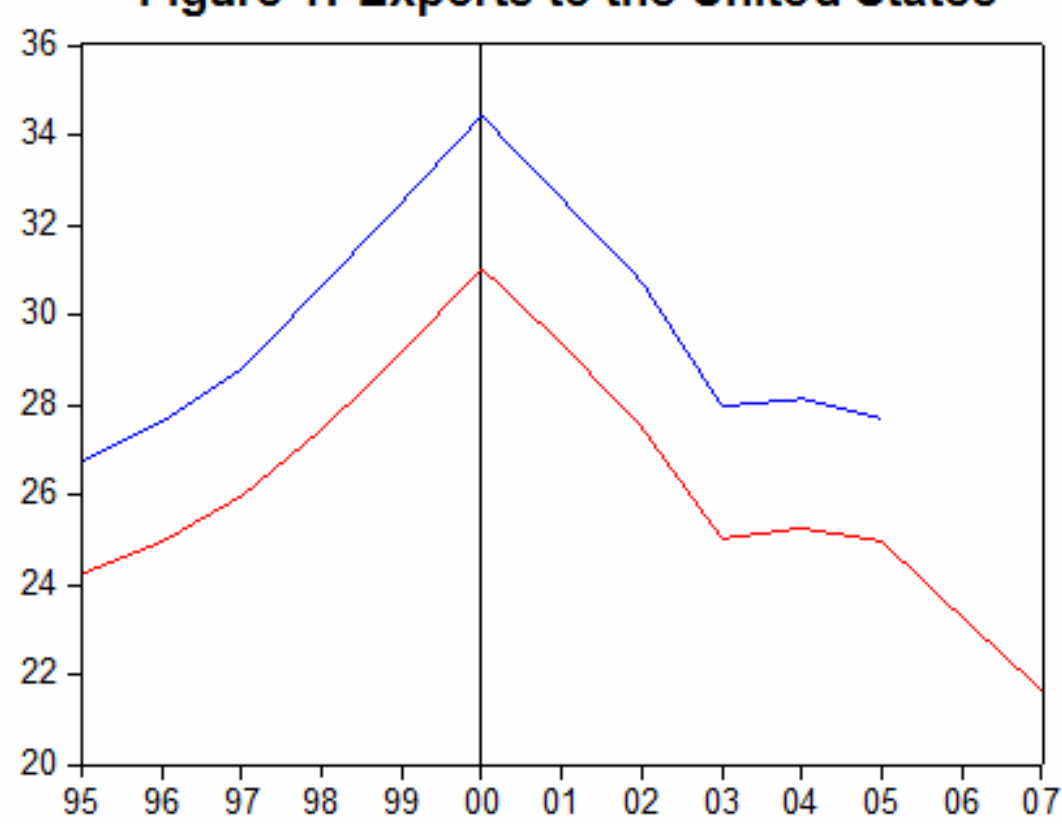

Exports plus service receipts

Exports of goods on customs basis 
Figure 2: Exports to the United States

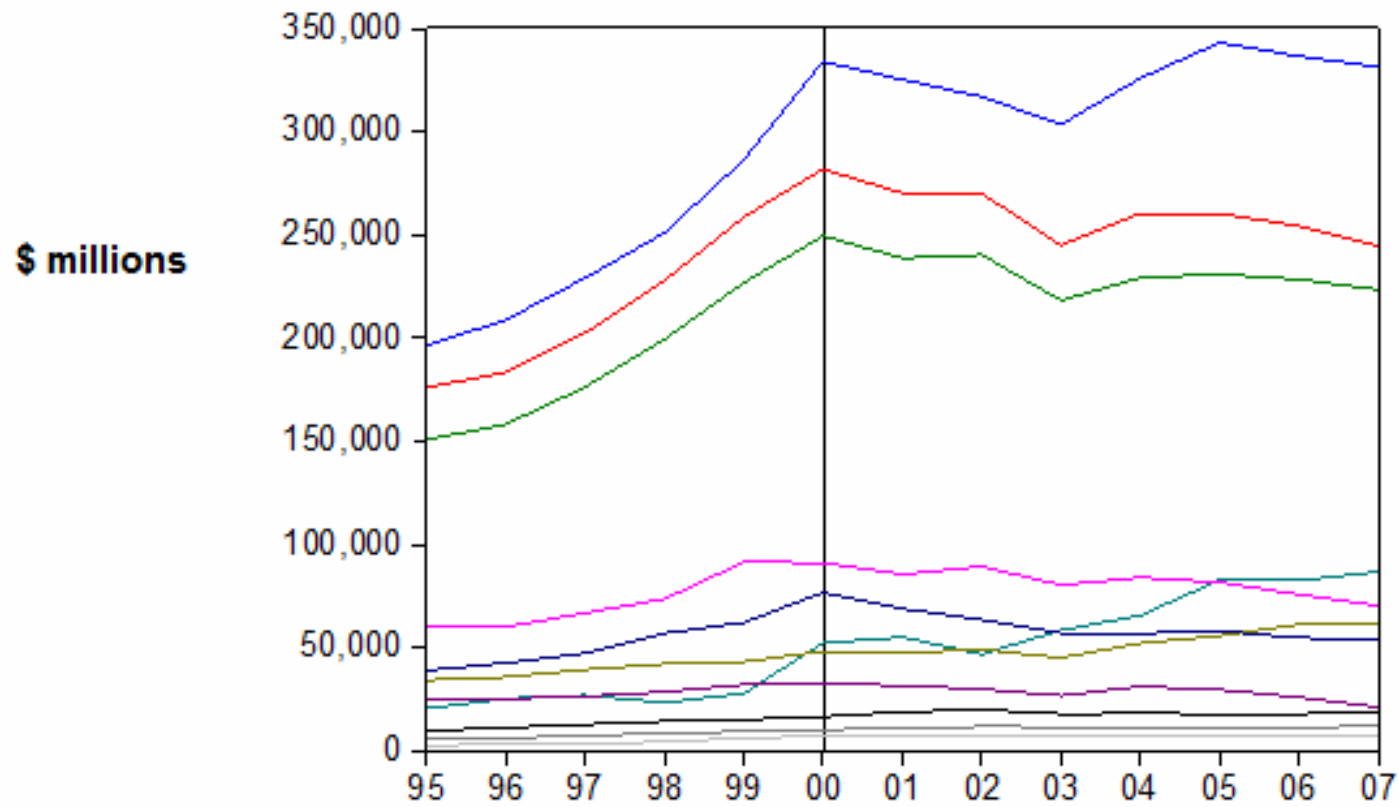

Total

Total excluding Energy

Total excluding Energy and Forestry Products

Agriculture and Fishing Products

Energy Products

Forestry Products

Industrial Goods

Machinery and Equipment

Automotive Products

Consumer Goods

Special Transactions 
Figure 3: Exports to the United States

\$ millions 2002

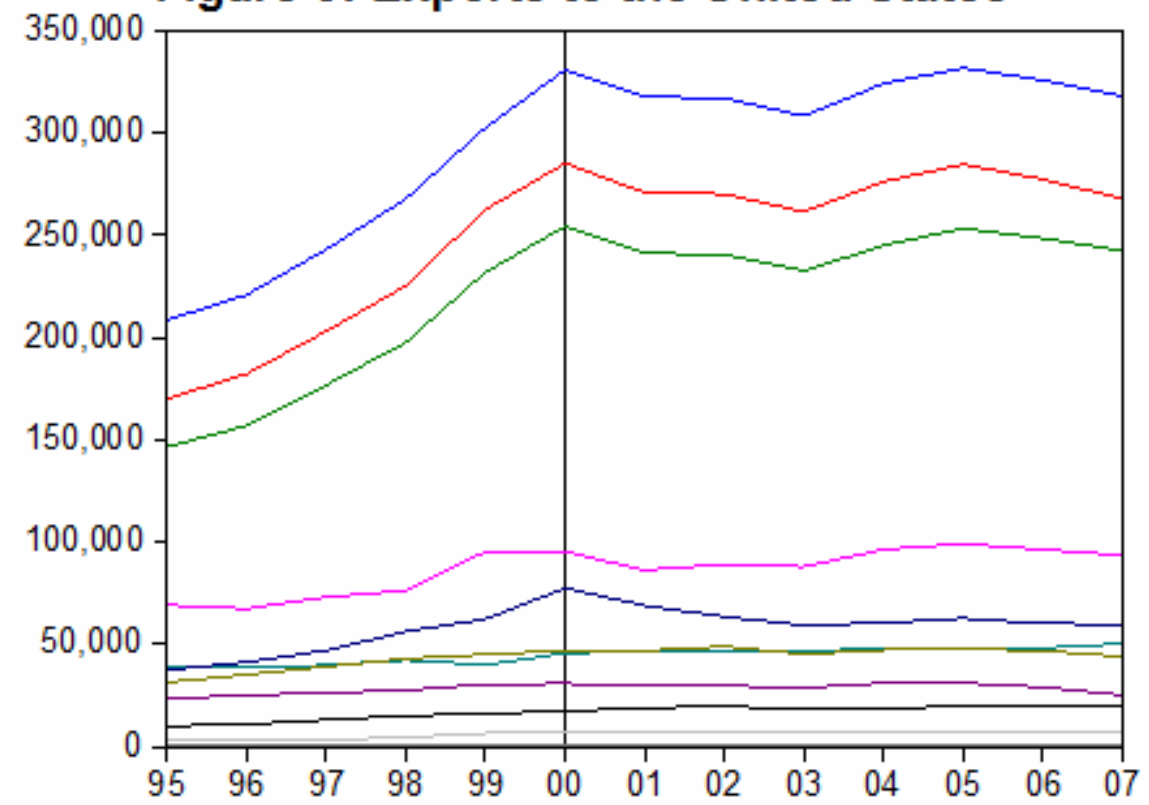

Total

Total excluding Energy

Total excluding Energy and Forestry Products

Agriculture and Fishing Products

Energy Products

Forestry Products

Industrial Goods

Machinery and Equpment

Automotive Products

Consumer Goods

Special Transactions 
Figure 4: Exports of Services to the United States

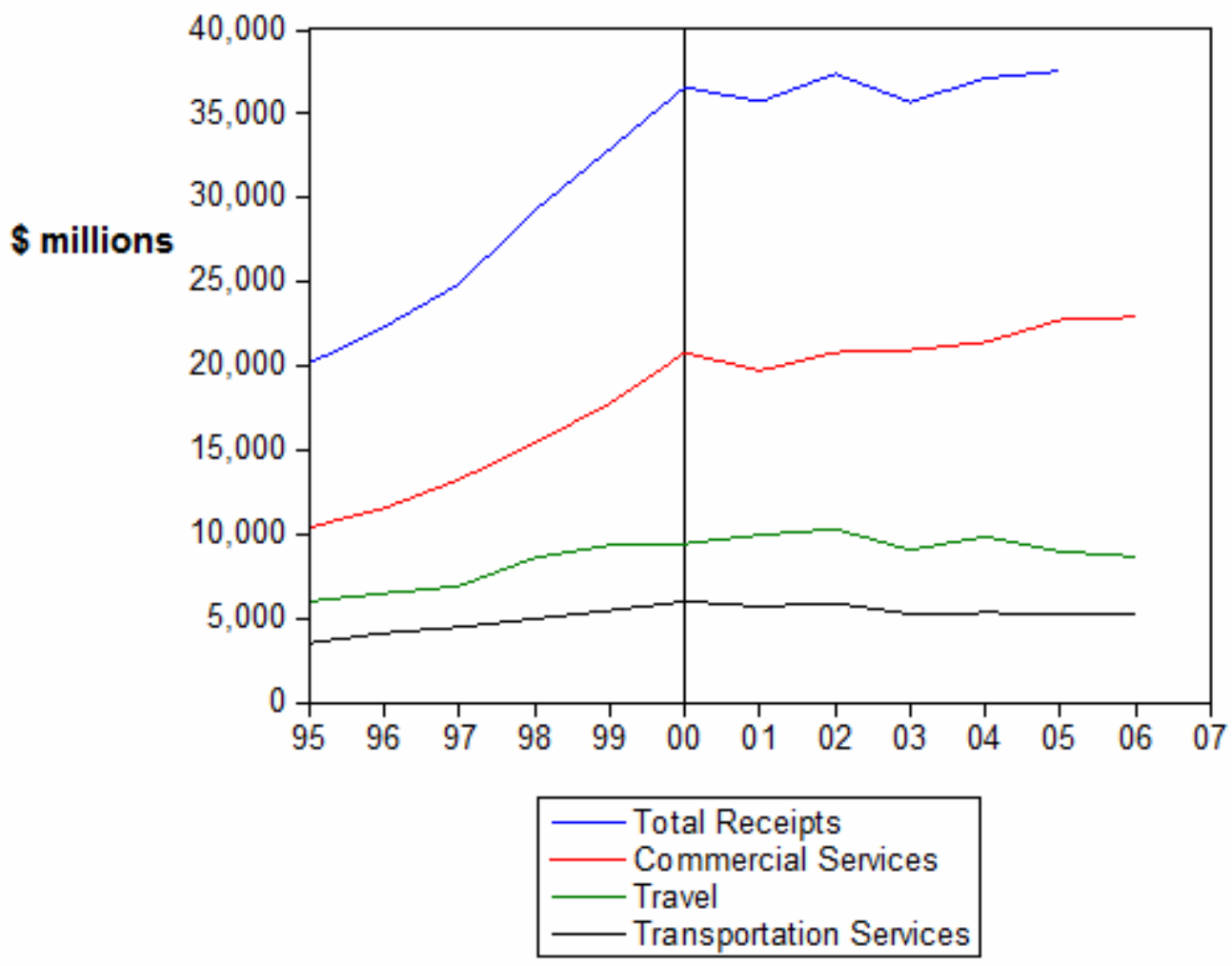


Figure 5: Exports of Travel Services to the U.S.

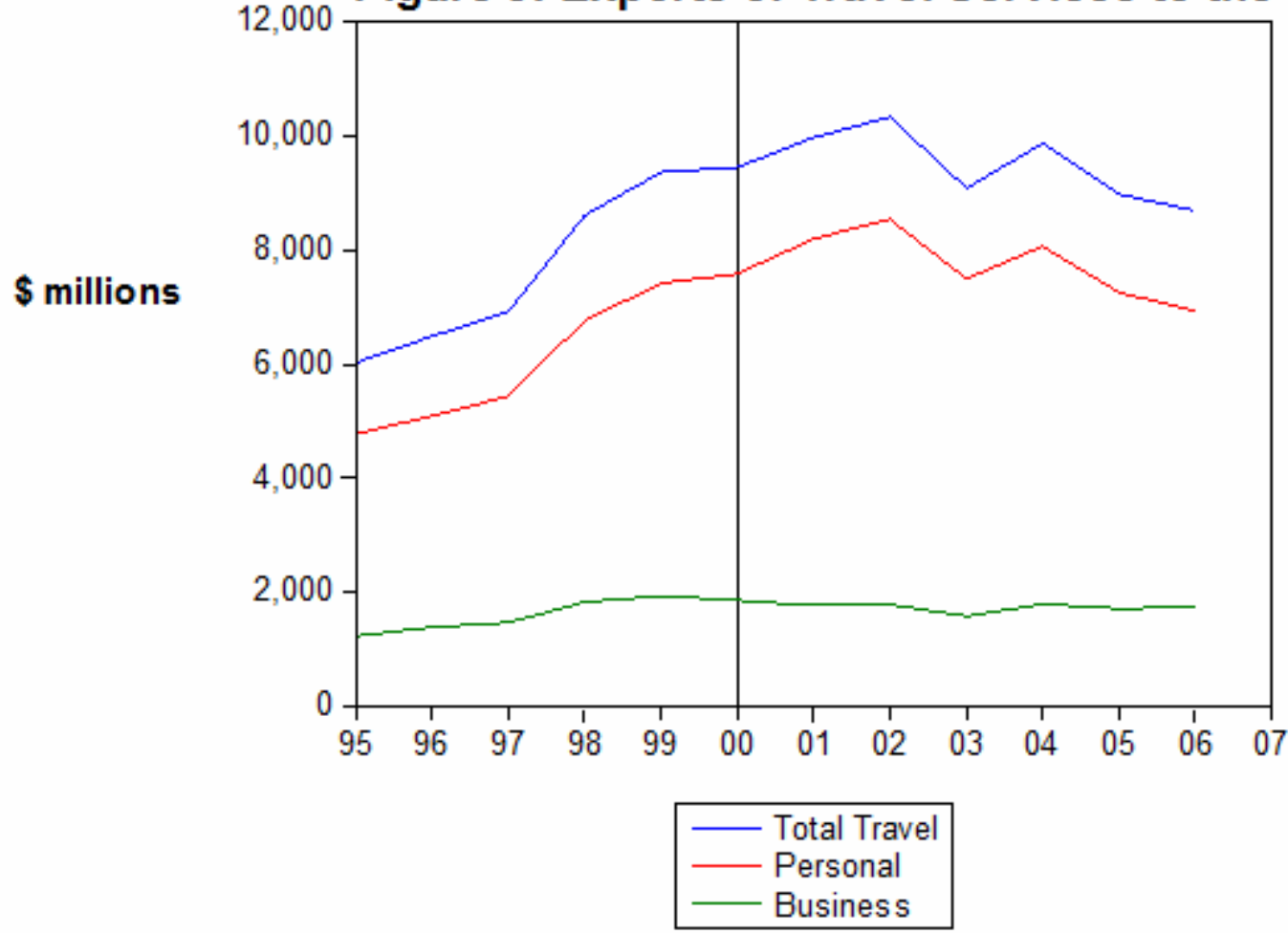


Figure 6: Exports of Transportation Services to the U.S.

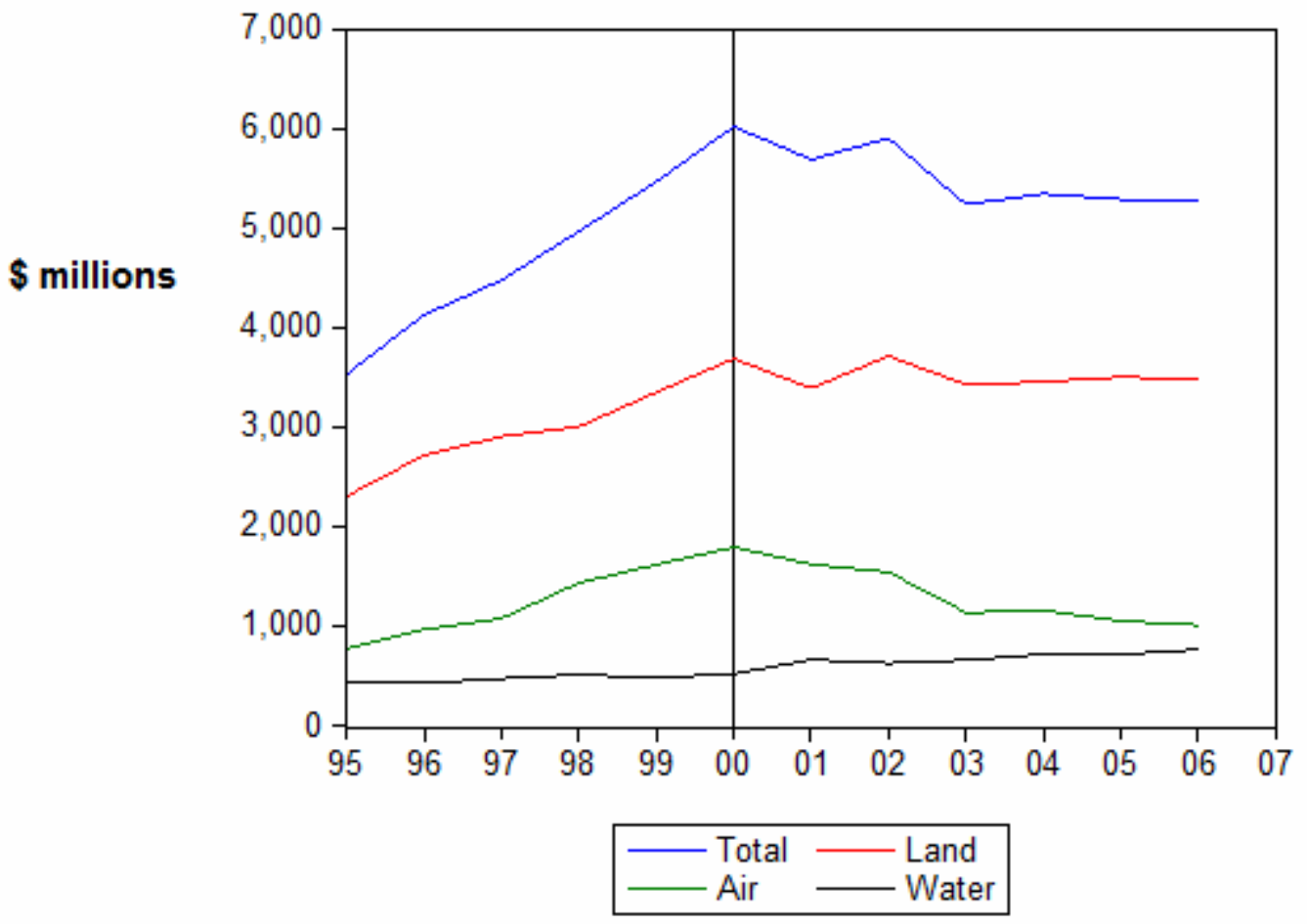


Figure 7: Imports of Travel Services

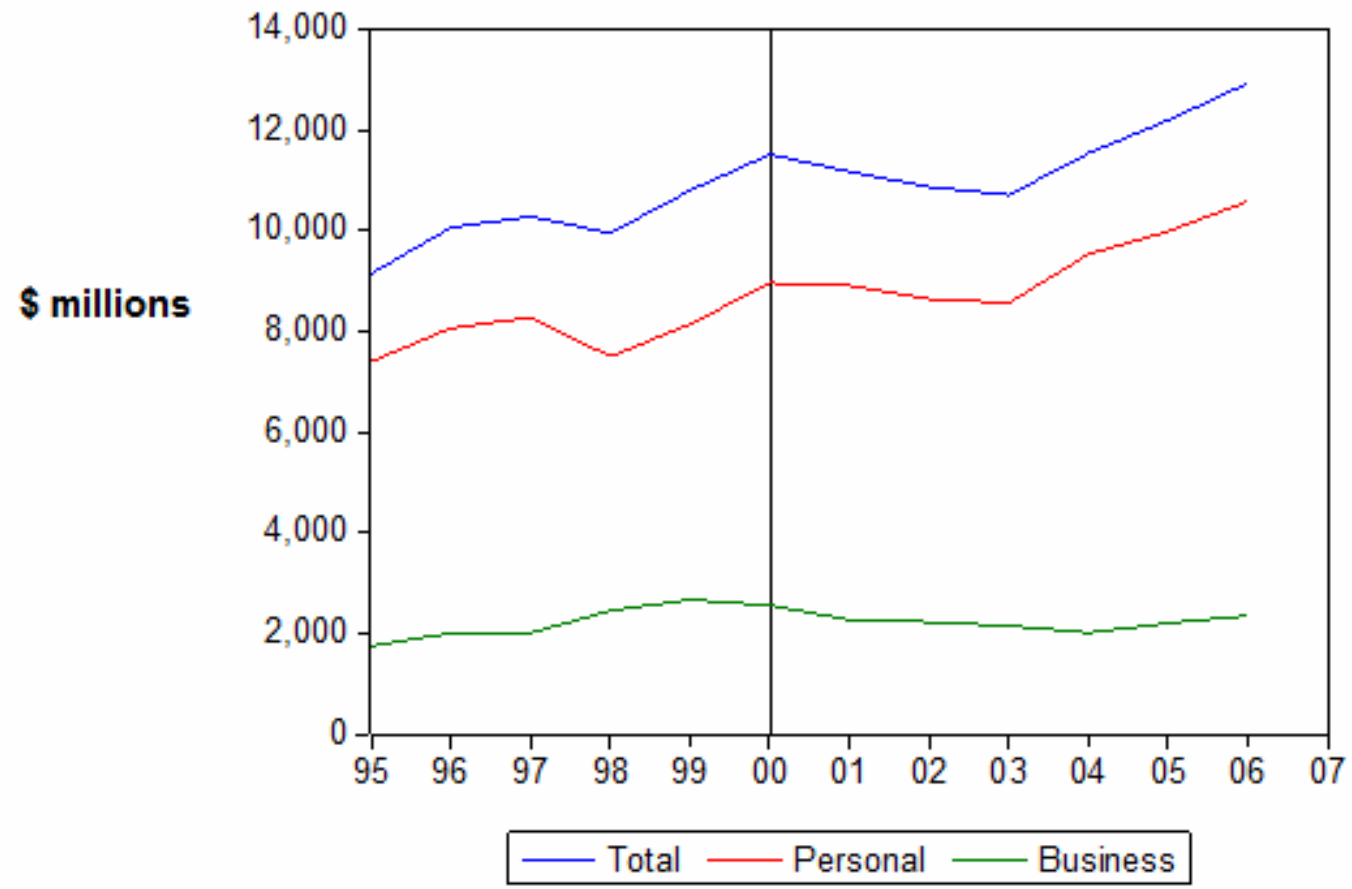


Figure 8: Imports of Travel Services in Current and Constant Dollars

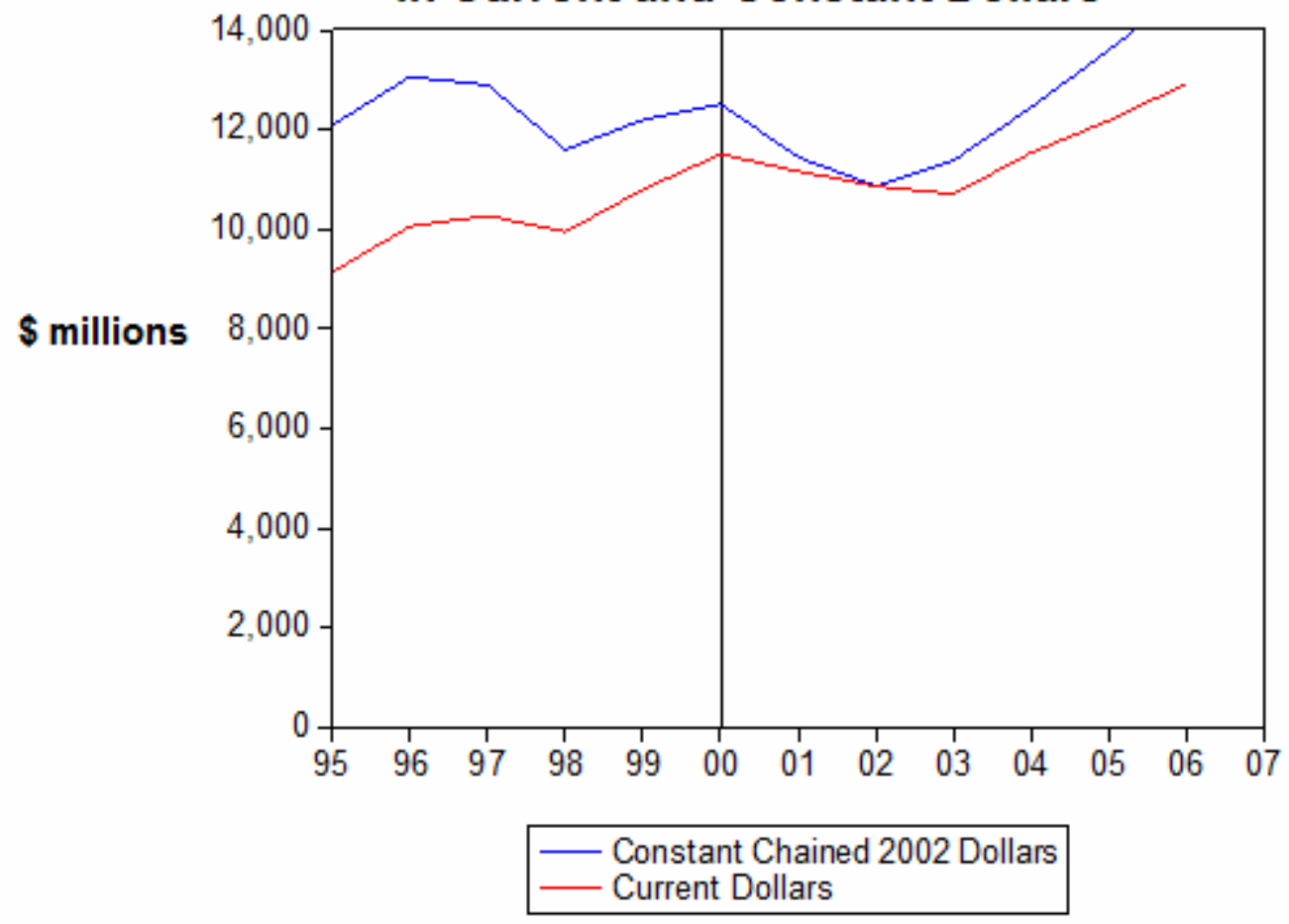


Figure 9: Estimate of Thickening of Border After 9/11

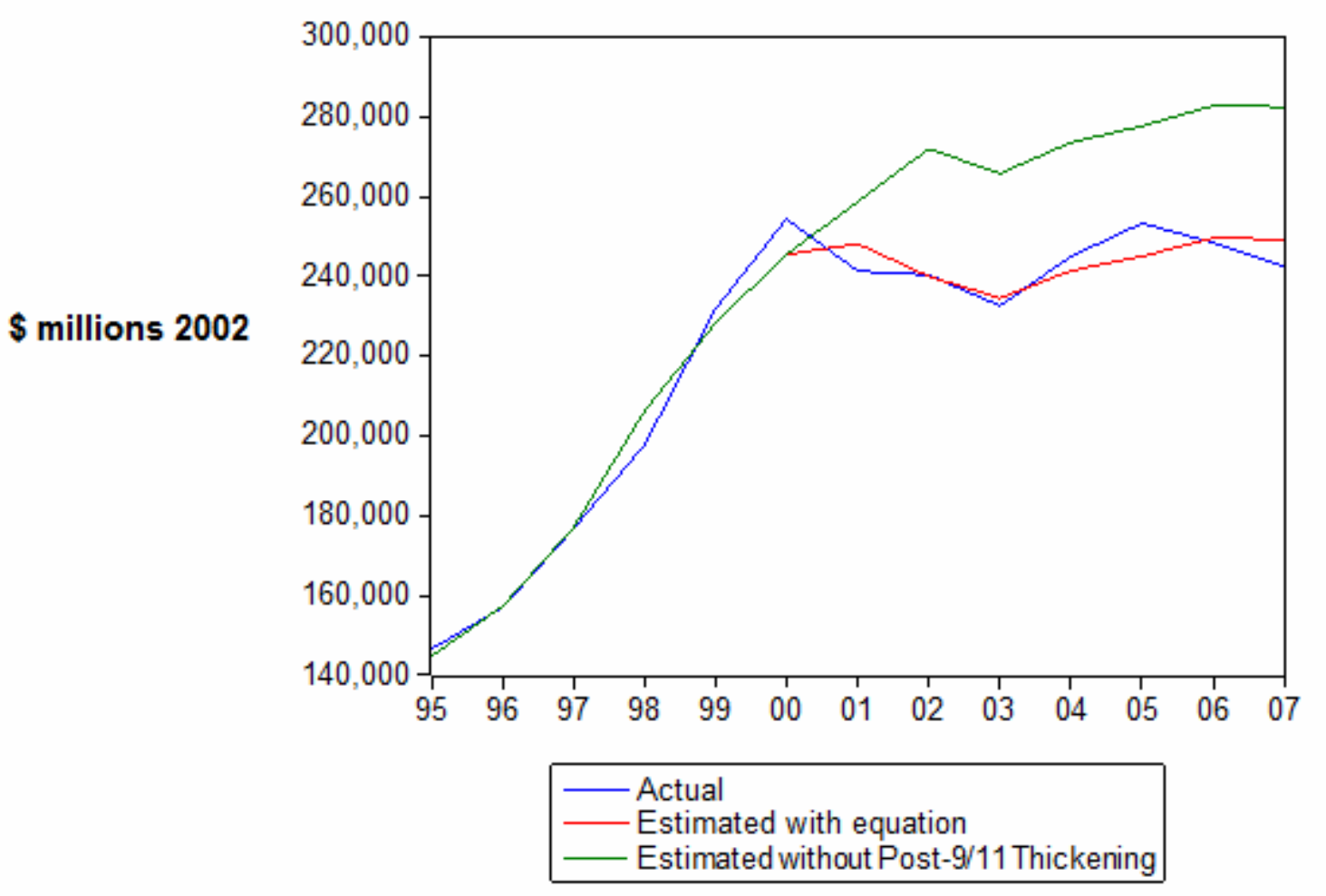

